\title{
Luxemburg's Dilemmas: Lessons in Marxism as Political Praxis
}

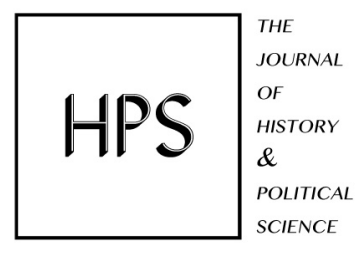

HPS: The Journal of History \& Political Science

2017, Vol. 5 64-73

(C) The Author(s) 2017

\author{
Carter Vance \\ Carleton University, Canada
}

\begin{abstract}
This article investigates the tensions in the writings of Rosa Luxemburg as juxtaposed to her historical contemporaries in light of the debate on reformist Marxism. Primarily, her exchanges with Eduard Bernstein on the question of social revolution and with Vladimir Lenin on the question of nationality are explored. In relating these debates to present day examples of social and protest movements, as well as those for national independence, the article attempts to tease out guidance for Marxist political praxis in the current day. By close reading of the Bernstein-Luxemburg debate, it can be seen that the "reform or revolution" debate is often posited in terms that are inconsistent with those the authors originally meant. The article posits that there is no inherent tension or dichotomous relationship between reforms and revolutionary practice as consistent with the way the terms are normally used today. At the same time, it raises questions about what the practical limits of Marxism as both an analytic framework and a guide to political action are, particularly on the question of nationalism.
\end{abstract}

\section{Introduction}

After his death in 1883, the influence of Karl Marx's ideas and writing grew rapidly, with many parties across Europe, most taking on a mantle of "social democracy," staking their political projects on Marx's critique of the by-then dominant capitalist mode of production. Indeed, it is no small feat that when we in the $21^{\text {st }}$ century speak of "socialism," we refer to a mode of political thought and action that, to varying degrees, draws its power from Marx's thought. That being a combination of classical English political economy with German philosophical dialectics and early, largely French, social justice authors. It is important to remember, especially when reading those that followed him, that Marx was not the first socialist, though he often appears that way to the modern learner. Much of the 
debate that surrounded interpretation of Marx's thought in its early years was in how his new system of "scientific socialism" and what would come to be critiqued as "an idealist explanation of socialism" differed from each other. This led into further debates about what made the former superior super to the latter as not only social theory but as a matter of onthe-ground politics.

Those convinced of the correctness of Marx's interpretation of history and political economy nevertheless faced a problem in moving those ideas from the realm of theory to that of praxis. The debates between Marx's acolytes at the beginning of the $20^{\text {th }}$ century, though they concern in some part questions specific to the time and place of their origin, nevertheless hold important, enduring lessons for people looking to accomplish the same goals over a century on. Ideas of reforms versus revolution, the tactics and methods of Marxist parties, the question of nationalism and cultural identity and just what it is that a Marxist ought to really do to advance her aims in the real world careen through the work of Rosa Luxemburg and her contemporaries. In highlighting but three of these, on the nature of scientific versus ideological socialism, on the question of reformism and on the relationship of Marxism to national self-determination, I hope to elucidate some points of general agreement in the debates of the time, which may help to inform some principles for our own.

\section{A Note on History}

To understand the debates which animate Luxemburg's writings thoroughly, however, some additional context is in order. No more so was Marx's influence apparent than in his native Germany. By the turn of the $20^{\text {th }}$ century, the German Social Democratic Party (SPD) was both the largest vote-earner in German elections and the largest Marxistinfluenced party in the world at that time. Luxemburg was an active member of party, as well as several other Marxist groupings throughout Central and Eastern Europe. Her positions in Reform or Revolution (1900) and The Mass Strike (1906) were articulated in opposition to a tendency within the SPD led by Eduard Bernstein, which critiqued some aspects of particularly early (circa Communist Manifesto) writings by Marx, suggested that capitalism might be ended by peaceful, parliamentary means and looking for ethical, as opposed to purely material, foundations to socialism. Bernstein's thoughts and works would later become highly influential in developing the theoretical background to what we might recognize as "social democracy" in the modern sense.

Luxemburg, by contrast, was a convinced, and often convincing, spokeswoman for the necessity of revolutionary action against capitalism. Her founding of the Spartacist League, along with fellow former SPD member Karl Liebknect, latter led to the infamous uprising bearing the group's name, which was crushed by reactionary remnants of the German Imperial Army under the orders of the Social Democratic Chancellor Friedrich Ebert, during which both Luxemburg and Liebknect were killed. Interestingly, in the instance of the German World War I vote for war credits which created a split in the Social Democratic Party, both Bernstein and Luxemburg were on the anti-war side. This points to the fact that the question of "reformism" as it was debated between the two is less in the common sense of watering down a program than about tactics given historical and developmental realities. 
Influential as it was, though, Marxism as an organizing political principle, let alone a party program, left a good deal of gaps to be filled by those that followed in the man's own footsteps. A large amount of Marx's work was left unfinished and his existing work only hinted around the edges at what principles might organize a post-capitalist world. As was eloquently critiqued by Rowbotham (1998) in the person of Annette Devereux, Marx was resolutely critical sometimes to the point of dismissiveness about concrete proposals for what a post-capitalist world would look like. ${ }^{2}$ Marx believed that it was factors of economic production, the organization of how things are produced and distributed, that moved history, not the ideas of women and men in and of themselves. Under a certain, resolutely unimaginative, interpretation that would mean that all there is for the self-described "Marxist" to do is to encourage the development of productive forces under a capitalist production mode until the whole edifice collapses under the weight of its own contradictions. Of course, such a proposal is a poor thing to build a mass political party hoping to gain power around. As such, activists, writers and theoreticians working in the tradition were forced to pull at the threads and squint into the penumbras of Marx's existing works for guidance in building a program for action. It is in this pulling and squinting that the first debates amongst Marxists were formed, and where we can begin our investigation.

\section{"Scientific" and "Ideological" Socialism}

The sometime difficulty in reading works of political theory over a century old is that terms with which we believe we are familiar appear, but mean something different than our current understanding. Much of the confusion that often arises in reading the work of Luxemburg and her contemporaries, such as Vladimir Lenin, is along these lines. Words like "reform," "revolution," "self-determination," "progressive," "democracy," and the like are infinitely malleable concepts that have taken on a wide variety of meanings over time.

Seen in this light, it should be clear that when Luxemburg writes against "reformism," she is expressly not making the argument that Marxists should simply wait around for things to get worse. They should not be unconcerned with the daily conditions of workers and simply organize for the moment of revolutionary overthrow. Indeed, at the very beginning of Reform or Revolution, she states that the "daily struggle" for reforms "offers to the SocialDemocracy an indissoluble tie" to the workers. ${ }^{3}$ Rather, what Luxemburg takes issue with is a tendency, embodied by Bernstein, which sees these reforms as the point in and of themselves of Marxist political action, rather than as a means to organize, agitate and raise consciousness for revolutionary aims. The crucial point to note is that Bernstein's theory saw not merely the amelioration of what we might call the sharp edges of capitalism but rather the end of capitalism itself as achievable through a process of reform. Taking, for instance, labour legislation limiting the working day as "piece of socialism" ${ }^{4}$ as Bernstein does, makes a certain kind of sense in that it is a reform that socialist parties supported and agitated for, and may be said to make life under capitalism "more resemble" that under socialism. However, to understand why even the most favorably-regulated workplace would still not necessarily lead to the achievement of or social appetite for an end to capitalism, we must return to Marx's critique of ideology, and his notion of the driving forces of history. 
Recall that, in The German Ideology, Marx states: "not criticism but revolution is the driving force of history, also of religion, of philosophy and all other types of theory." ${ }^{15}$ this context, "revolution" should not be read, as it so often is, as "violent insurrection" but rather as "fundamental change in the system of production of goods within a society". This is not to say that the two are totally unrelated, as they do often predict and follow from each other, but that they are not one in the same and that an explosion of social tension does not necessarily a revolution make. Rather, a revolution must involve the displacement in a position of social dominance of one class by another. In the transition from feudalism to capitalism, for instance, the class of traditional nobility was supplanted by that of the bourgeois. It is only through control and shaping of a society's production methods that a class attains this positon, which is where Bernstein's argument comes unglued and consists primarily of a variety of political/ethical "criticism" of capitalism without an aim by which socialism is actually achievable. As Luxemburg states, he "renounces the socialization of production and merely proposes to reform commerce." ${ }^{\prime \prime}$ No doubt, reforming commerce, meaning a wide variety of things from the development of cooperatives to redistribution via taxation, would be a very good thing. However, it lacks a definite aim beyond that of "making the poor rich," a sort of nice notion lacking rigor to understand why it is unachievable absent revolution.

Before writing off Bernstein's reformism entirely, however, a few points can be spoken in its favour that those inclined to side entirely with Luxemburg should keep in mind. Firstly, Bernstein's theories were not conjured out of thin air. They had a basis in observable facts about the nature of capitalist development since Marx's death that did not seem to bear out Marx's predictions of capital concentration and collapse. Medium-sized firms proliferated, for example, and there was general economic growth which, coupled with increased trade union struggle in Germany, led to higher living standards for workers. It can seem still that capitalism is more dynamic and less concentrated than ever if one reads about the mass of tech start-ups or other new shiny objects conjured up on a seemingly daily basis. There is an answer for this, however, in the observation that small enterprises "rapidly grow up, only to be mowed down once more by large industry." 8 In modern terms, we can think of this as the divide between dominant monopolies and oligopolies and the small innovators which are rapidly purchased or otherwise coopted by them.

More convincingly, though, it is true that the relentless focus on the working class as the main driver of the current epoch of history can lead to a myopic focus on its oppressions and struggles as the only "real" or "scientifically valid" ones. This can often leave many persons from socially oppressed groups (women, racialized persons, Indigenous persons, Queer persons, etc.) alienated from Marxist theory, as they feel it does not speak to their lived realties, even if they also experience material exploitation on the basis of being a member of the proletariat. As Marx stated, "every new class, therefore, achieves its hegemony only on a broader basis than that of the class ruling previously." Actions, or lacks thereof, which potentially limit the social base for a revolution in production mode leading to socialism therefore can be judged as a praxis error. In critical comments on Luxemburg's tendency within the SPD of the time, Ernesto Laclau and Chantal Mouffe observed that "revisionism, at its best moments, represented a real effort to break with the corporative isolation of the working class." ${ }^{10}$ Similarly, the engagement with movements for social justice without an explicit basis in class struggle in the current age may be judged as "unscientific" by some, but it is undoubtedly necessary for building this social base. 
With this said, two things must be true in order for socialism to be potentially achievable. Firstly, as per Marx, there must be a sufficient development in the productive forces of society under capitalism in order to both make socialism concretely livable (sufficient development of efficient machinery, the ability to create a general surplus of goods, etc.). Following from that, a proletariat must exist in sufficient numbers to be the majority of people in society with a material interest in seeking capitalism's end. Secondly, these concrete facts are not enough, as there must be a "comprehension of that necessity"11 on the part of the proletariat themselves. The aim of engagement in reform projects, from the long-term Marxist perspective is to increase this "comprehension". In other words, she believes that Bernstein, in neglecting the need for a socialist vision of the future to rest fundamentally upon the transformation of the capitalist mode of production, meaning that characterized by alienated labour, exploitation of labour time and commodity fetishism, has returned to an "ideological" pre-Marx utopian socialism without a basis in historical and scientific analysis. To be clear, his error is not seen to be that he is not ready to pick up a rifle and rush to the barricades tomorrow, but that he mistakes the necessity of reform for an aim and thereby mistakes reform itself for revolution.

It is a mistake to believe that Luxemburg's status as a "revolutionary" Marxist means that she was always advocating the most immediate overthrow of the status quo. By contrast, in perhaps her most extensive work on political tactics, 1906's The Mass Strike, the material conditions of a situation are seen as the main determining factor in which tactics can be effectively used to advance revolutionary ends. ${ }^{12}$ In examining the course of a series of general strikes in south Russia in 1903, she observes that a revolutionary moment in society arises from "many small channels of partial economic struggles and little 'accidental' occurrences." ${ }^{13}$ In these struggles, the political consciousness and thereby the impetus for a set of demands Luxemburg identifies as "revolutionary" around the end of absolutism in the political form of the Russian state were forged. It is critical to note that these demands, which culminated in the Russian Revolution of 1905, were chiefly advanced by the "fighting strikes" based around economic struggle and not the "purely political demonstration strikes" explicitly predicated on political demands. The political grows out of the economic, in other words, though it is also true that changes in the political situation or character of a state can open new plains for economic struggle.

The mass strike, along with any other potentially revolutionary tactic, as both a historical moment and a political action, therefore, is not something that can be "carried out by the decision of the highest committees and furnished with a plan and panorama." ${ }^{14}$ To the contrary, it arises from definite political situations which are often built up by a series of reform-based struggles. The mass strike is not "one isolated action" 15 in this context, but rather an external expression of the pre-existing state of the class struggle at that time. Socialists and their parties have a role in shaping the situations as they arise, but they err in placing certain tactics on the "revolutionary" pedestal in all instances, and in assuming the political mass strike will at all times be effective. 


\section{Reformers and Revolutionaries}

The problem of contrasting a gamut of tactics ranging from electoral participation to peaceful protests to trade union activity with an act of "revolution" is that this is a false dichotomy. It populates the "revolutionary" position with only the violent, one-fell-swoop "revolutionary" action of the popular imagination, rather than its actual meaning in Marxist thought. This is not the kind of division that Luxemburg was advocating in 1900 when speaking against movements towards "reform."

In the current day, we might think of this in terms of the "Fight for 15" movement for significant increases in the minimum wage along with other improvements to workers' legal rights and working conditions as a point for Marxist praxis. It is undoubtedly true that a minimum wage of fifteen dollars per hour would improve the lives of those working in minimum wage occupations, and that the experience of collective political action (strikes, protests, etc.) in the service of these goals would serve to raise the political consciousness of those who are involved in it. This is likely more the case in our current reality than in Luxemburg's time, given the atomization of labour processes, the decline in traditionally concentrated factory employment and the drop-off in trade union membership since the end of the 1970s. For many, participating in and, more crucially, winning tangible gains as the result of participating in Fight for 15 will be their first experience of actual political action, which can lead to further engagement and greater consciousness of their own position in the current social and economic structure. It therefore is completely advisable for Marxists to involve themselves in these projects for the sake of strengthening that "indissoluble tie" of reform, whilst recognizing that such reforms are only potentially revolutionary, given the conscious recognition of their place is not revolutionary in and of themselves. In Luxemburg's parlance, it is through agitation that these "mere economic struggles for wages" can take on a more revolutionary character.

In this sense, what the socialist of the early $21^{\text {st }}$ century, quite like that of the early $20^{\text {th }}$, ought to be working for is what can be termed reforms for non-reformist purposes. That is to say, the seeking of reforms in all varieties, and with all groups of oppressed peoples, which will ameliorate their immediate circumstances, but with the underlying aim the creation of revolutionary consciousness and momentum. The seeking of total ideological purity in a small group of those who believe they already possesses the ancient truths that the masses are simply too ignorant to recognize misstates the purposes of the anti-revisionism argument as stated by Luxemburg. In reality, there is no conflict in engaging with groups and movements we may not agree with in totality, as long as they will strengthen the link of Marxists with the working class and build a broader base of support, on the basis of reforms, and believing in a revolutionary cause in the final instance.

\section{Wither the Nation?}

The proximate cause of Luxemburg's initial (pre-Russian Revolution) split with Vladimir Lenin, though they are both often seen as emblematic of the revolutionary Marxist tendency, was over the question of nationality and self-determination. To some extent, these debates turn on specific questions regarding the precise political composition of Central and 
Eastern Europe and the time of their writing. Nevertheless, they do speak to some key contradictions in the struggle to apply Marxism politically.

It is doubtless true that the call for the "right to national self-determination" was a key part of the ideological appeal of Marxism across the Global South in the $20^{\text {th }}$ century. It would not be an exaggeration to say that Marxist groups of various sorts were the most effective forces in ending straightforward colonial occupations and creating some space for national independence in this time period. Lenin's determination of the right to selfdetermination does not rest on an abstract ideal, but rather on a basis of the nation occupying a oppressed positon relative to another, oppressor nation (in the case of his examples, the latter is Russia). ${ }^{16}$ Luxemburg, in turn, accuses him (or, more specifically, the Russian Social Democratic and Labour Party) of extrapolating particular, material cases into an abstract, ideological principle which is not supportable or supported by socialist parties in many instances where centralization was more materially progressive. What this, in essence, indicates is that, once we move beyond the obvious and straightforward examples of colonial domination, where the sympathies of a Marxist ought to lie in a question of "national self-determination" is far less clear.

How, for instance, should Marxists have felt about the Boer War? Certainly, a reading of the situation could view it as a struggle for self-determination by the Afrikaners against British imperialism. However, this would also ignore both the existing colonial nature of the Boer Republics and what Lenin would likely describe as their "backward and reactionary"17 economic and political character.

Closer to home, would a Marxist have judged the establishment of an independent Quebec to be within the right to self-determination or not? Again, the question is not straightforward, due both the colonial nature of the relationship that an independent Quebec would have had with its Indigenous population and the questions surrounding antiimmigration sentiment in the independence referendum.

As can be seen from these examples, the question is far more complicated than it at first appears. In this light, it may be analytically easier to take Luxemburg's position and simply state that the idea of solving nationality questions, and the related ones of race, ethnicity and the like, via self-determination under a capitalist system is simply "a complete utopia." ${ }^{18}$ Therefore, we ought to be more concerned about ending capitalism as a first priority, and then sorting out those other questions afterwards.

However, for those populations experiencing super-exploitation as a result of their marginal position in the capitalist production mode, self-determination, this is likely to smack of naivety if not the ignorance borne of relative prosperity. Think, for example, of what a true right to self-determination, up to and including succession, would mean for Indigenous nations in Canada or other settler-colonial states, even given their insertion as independent states into a global capitalist framework. It could be seen as the equivalent of those reforms which, whilst not revolutionary in and of themselves, nevertheless, forge and strengthen the "indissoluble tie" of Marxism to the masses, albeit through a vector not explicitly conditioned on the directly amelioration of working/living conditions.

Of course, there is danger in an embrace of nationalism, which can easily prove more reactionary and xenophobic than progressive. Lenin does recognize this potential in stating that "an independent appraisal of the advisability of the state secession of any nation in each separate case" ${ }^{\prime 19}$ should be done, regardless of the pre-existing right, to see if socialists ought to support secession in that instance. This nevertheless leaves the question of what ought to 
be done when the right is given and the advice of socialists to not secede is ignored. As well, if generalized, the right of self-determination must logically extend to oppressor nations as well oppressed, which can have massive material harm implications for minorities within those nations. There are other critiques of nationalism to be had, such as that it can encourage reactionary cultural expressions or regressive social movements based on the notion of a return to a mythological past, but these are numerous and more fully articulated elsewhere.

Perhaps it is best, therefore, to say that self-determination for an oppressed nation can be a reform for non-reformist purposes within a revolutionary framework, but that this character is conditional upon the particular material circumstances. This is not to downplay the very real oppression on account of nationality that can and does exist, but in the development of a clear, historical materialist account of nationality politics, there can be no recourse to an abstract.

\section{Socialism or Trumpism}

Much like Rosa Luxemburg and her contemporaries, we live in curious and dangerous times, fraught with oppression, violence, war and poverty. It is also a time of great social yearnings for something more than this current state of affairs, and a variety of social movements speaking to both the injustices of the world in which we live and the sense that a better one is not just possible but necessary. The trends of globalization under the framework of neoliberalism have shattered a previous uneasy social peace that existed between labour and capital in the post-World War II period (this is to say nothing of the expansion of capitalist production modes in the Global South, where such a peace was never achieved to begin with). The full extent of the new reality was, for a time, hidden from view to many due to the mass expansion of credit funds to consumers and a variety of other tricks of the accounting books. The 2008 financial crisis and its aftermath demystified and revealed the true nature of what the "new economy" had wrought for those not lucky enough to be in an ownership positon of our modern production means. From this, we have seen the emergence of a mass of political energy amongst a wide swath of the population on a scale not likely equaled since the 1960s.

However, before we entirely cheer this development, we must also heed Luxemburg's quotation of Friedrich Engels that "either transition to socialism or regression into barbarism" 20 is possible from moments of crisis in capitalism. In her era, the brutal imperialist slaughter of World War I shattered the widely-held illusions of "peaceful development" and "European civilization," as the mainstream social democratic parties across the continent voted their working classes into shooting and stabbing those of other nations. In ours, a discredited and ineffectual liberal reformist tendency seems almost totally incapable of combatting challenges from White ethno-nationalist movements across Europe and North America. These seek to solve economic problems by a further concentration of state surveillance and violence against various, usually racialized, Others and a return to what could be described as "tariff wars" sharpening contradictions between national states and international capitalism. ${ }^{21}$ Without a narrative that couples concrete reforms with the 
potential for revolutionary transformation, the Left as a collective is running the very real risk of becoming alienated from those it ostensibly speaks on behalf of.

It is far from determined, "scientifically" or otherwise, that, if capitalism were to come to an end, it would be socialism of the type Marx formulated which would reign victorious. In order to make sure that this is the case, Marxist praxis must once again embrace the notion that reform and revolution are not opposed, nor are their means necessarily different. The point is more, as stressed in The Mass Strike, to recognize the characteristics of the current moment, and to adapt tactics to those characteristics. Otherwise, the social base for any potential revolutionary movement inevitably shrinks, and, conversely, that for a reactionary or regressive movement may grow. If the development of this kind of praxis is possible, then perhaps we could begin to speak of the potential of a world where, "there would then be only one right - the equality of all men [sic.]. There would only be one aimthe prosperity and progress of all." 22

\section{NOTES}

${ }^{1}$ Rosa Luxemburg, Reform or Revolution, 1900/1908 trans. Integer (London: Militant Publications, 1986), reprint, (Marxists Internet Archive, 1999), part 1, chap. I, n. pag., accessed September 17, 2016, https://www.marxists.org/archive/luxemburg/1900/reform-revolution/index.htm.

${ }^{2}$ Sheila Rowbotham, "Dear Dr. Marx: A Letter from a Socialist Feminist," Socialist Register 34, (1998), accessed September 17, 2016, http://socialistregister.com/index.php/srv/article/view/5698/2594.

${ }^{3}$ Luxemburg, Reform or Revolution, (1900/1908), "Introduction," n. pag.

${ }^{4}$ Ibid., part 1 chap. III, n. pag.

${ }^{5}$ Karl Marx, Friedrich Engels, and C J Arthur, The German Ideology (New York: International, 1972), 17.

${ }^{6}$ Luxemburg, Reform or Revolution, (1900/1908), part 2 chap. IX, n. pag.

${ }^{7}$ Ibid., part 2 chap. VI, n. pag.

${ }^{8}$ Ibid., part 1 chap. II, n. pag.

${ }^{9}$ Marx, Engels, and Arthur, 22.

${ }^{10}$ Ernesto Laclau and Chantal Mouffe, Hegemony and Socialist Strategy: Towards a Radical Democratic Politics, (London: Verso, 1985), 30.

${ }^{11}$ Luxemburg, Reform or Revolution, (1900/1908), part 2 chap. VI, n. pag.

${ }^{12}$ Rosa Luxemburg, The Mass Strike, the Political Party and the Trade Unions, 1906 (Detroit: Marxist Educational Society of Detroit, 1925) reprint, (Marxists Internet Archive, 1999), n.pag., accessed September 17, 2016, https://www.marxists.org/archive/luxemburg/1906/mass-strike/index.htm.

${ }^{13}$ Ibid., chap. III, n. pag.

${ }^{14}$ Ibid., chap. IV, n. pag.

${ }^{15}$ Ibid.

${ }^{16}$ Vladimir Ilyich Lenin, "The Right of Nations to Self-Determination," Prosveshcheniye 4-6 (1914) in Collected Works Vol. 20 trans. Bernard Isaacs and Joe Fineberg (Moscow: Progress Publishers, 1972) 393-454, reprint, (Marxists Internet Archive, 2004), n. pag., accessed September 17, 2016, https://www.marxists.org/archive/lenin/works/1914/self-det/index.htm. 
${ }^{17}$ Vladimir Ilyich Lenin, "Theses on the National Question," 1913/1925 in Lenin Collected Works trans. George Hanna (Moscow: Progress Publishers, 1977): 243-251, reprint, (Marxists Internet Archive, 2004), s. 1 (d), accessed September 17, 2016, https://www.marxists.org/archive/lenin/works/1913/jun/30.htm.

${ }^{18}$ Rosa Luxemburg, "The National Question," Przeglad socialdemokratyczny (1909) in The National Question-Selected Writings by Rosa Luxemburg ed. Horace B. Davis (Monthly Review Press, 1976), reprint, (Marxists Internet Archive, 2008), chap. 1 s. III, accessed September 17, 2016, https://www.marxists.org/archive/luxemburg/1909/national-question/index.htm.

${ }^{19}$ Lenin, "Theses on the National Question," 1913/1925, s. 4.

${ }^{20}$ Rosa Luxemburg, "The Junius Pamphlet: The Crisis of German Social Democracy," in Politische Schriften (1916), 229-243 and 357-72 and The Junius Pamphlet (The Merlin Press, London: 1967), reprint, (Marxists Internet Archive, 2003), chap. 1, n. pag., accessed September 17, 2016, https://www.marxists.org/archive/luxemburg/1915/junius/index.htm.

${ }^{21}$ Luxemburg, Reform or Revolution, (1900/1908).

${ }^{22}$ Rosa Luxemburg and Karl Liebknect, "Manifesto of the German Spartacists," The Call, January 30, 1919, reprint, (Marxists Internet Archive, 2007), n. pag., accessed September 17, 2016, https://www.marxists.org/history/international/social-democracy/call/1919/30.htm. 